\title{
Language Styles in Corruptor Narrative Free of Corona? Later Used Najwa Shihab in YouTube
}

\author{
Widya Husin ${ }^{1, *}$ Yenni Hayati ${ }^{1}$ \\ ${ }^{1}$ Postgraduate Program, State University of Padang 25171, Indonesia \\ *Corresponding Author. Email:widyahusin06@gmail.com
}

\begin{abstract}
This study aims to describe and explain the use of Antonomasia's figurative language style and cynicism in the narrative the corruptors were freed because of corona? You will be on YouTube first. This study describes the use of Antonomasia's figurative language style and cynicism used by Najwa Sihab to criticize political elites in the midst of Covid 19. The research method used in this research is descriptive method. The source of the data in this research is from Youtube with a video narrative delivered by Najwa Sihab. The data collection technique used in this study was the observation and note technique. The data analysis technique was carried out by describing the descriptive form of each data functionally and relational. The results show that the use of figurative language style is more widely used in the narrative of the corruptors being released because of the corona? In the past, najwa sihab on YouTube is a figurative style of Antonomasia and cynicism. Seen from the language style based on the direct meaning or not, which includes climax, anticlimax, parallelism, antithesis and repetition. Language styles based on direct meaning include rhetorical language styles including alliteration, assonance, apostrophe, asindenton, erotesis / rhetorical questions, and hyperbole and figurative language styles which include equality /simile, metaphor, parable, personification, and synekdoke styles.
\end{abstract}

\section{Keywords: language style, corruption narrative freed because of corona and YouTube}

\section{INTRODUCTION}

Language has an important role in human life, language is used to convey ideas or ideas that are in the mind. Humans use language as a means of communication and interacting in the surrounding environment or society. with the language of one's ideas or thoughts can be conveyed by using the four language skills, these four skills which make the use of language increasingly master the language itself. There are many ways humans convey their ideas or ideas, one of which is narration, the narrative used either orally or in writing will open the mind of the reader or listener, the narrative that is conveyed in oral form has many characteristics or language styles of each of the speakers, so that the narrative is not only densely packed with ideas or ideas it also becomes more attractive and more lively when juxtaposed with the language style in his speech. [1] Language style is a utilization of the richness of language by a person in speaking or writing. Language style is a typical way of expressing thoughts and feelings in written or spoken form. [2] linguistic style is a way of conveying thoughts through language in a distinctive way that shows the soul and personality of the writer (language user). language style based on sentence structure is divided into climax, anti-climax, parallelism, antithesis, and repetition. Language style based on direct meaning is divided into rhetorical language styles which include alliteration, assonance, anastroph, apophasis or preterisio, apostrophe, acindetone, polysindetone, chiasmus, ellipsis, euphemismus, litotes, proteronic hysterone, pleonasm and tautology, perifrasis, prolepsis or anticipation, erothesis or rhetorical inquiry, silepsis and zeugma, correction or epanortosis, hyperbole, paradox, and oxyinomorones. In addition, figurative language styles include similes or similes, metaphors, (allegories, parables, and fables), personification or prosopopoeia, allusions, eponyms, epithets, sinekdoke. Metonymy, antonomasia, hypalase, (irony, cynicism and sarcasm), satire, insuendo, antifrasis, pun or paronomasia.

[3] the language style based on the choice of word a uses formal and informal language styles and conversations but the most dominant is the conversational language style, the language style based on the tone uses noble and powerful language styles and for language styles based on sentence structure using parallelism, antithesis, and the repetitions which include tautotes and epizeuxis. [4] oxymoron language style to build credibility and litotes to build curiosity, using more varied language styles such as ellipsis, correction, metonymy while to beautify messages using assonance, apostrophe, and alliteration. At the conclusion of the lecture, assonance and hyperbole language styles were used to provide beauty and emphasis to the conclusion. 
[5] research on the style of language in Ustadz's lecture, the results show that the style of language in Ustadz Maulana's da'wah at Islamic events is beautiful, namely rhetorical language styles including repetition, alliteration, apostrophe, acindeton, pleonasm, tautology, erotesis, prolepsis, correction, and hyperbole, then figurative language style which includes similes, metaphors, and allegories. [6] conducted research on language style. The results showed that the use of diction and language style in Tengku Hanan Attaki's religious lectures, there were various types of meanings and language styles contained in the lecture. based on the data obtained in the Tengku Hanan Attaki religious lecture, there were more words that did not refer to the real meaning such as contextual meaning and connotation. The research results found are the use of types of meaning (classified into lexical, grammatical, contextual, referential, non-referential, contative, denotative, proverbial, collocative, thematic, general and special words, and slang), meaning relations (classified into synonyms and antonyms), and language style (classified into comparative language style, namely parables and metophores, linkage language style, namely antonomasia, and repetitive language style, namely epizeukis) in the Tengku Hanan Attaki religious lecture.

[7] in his research entitled the style of language in diwan imam syafi'i about the command to seek knowledge, in this article there are three discussions (1) language style, (2) diwan Imam Syafi'i, (3) and the command to seek knowledge. With these three discussions, it includes several discussions, namely some definitions, steps to analyze the language style that is in Diwan Imam Syafi'i, types of language style, and the function of language style. The research results from the analysis that has been carried out, there are 9 types of language styles found in 5 poems on Diwan Imam Syafi'i. However, the language style that is more dominant than the 5 poems is the simile language style.

[8] The results showed that there were 22 language styles used by students in their poetry; The personification language style dominates the language style in students' poetry, which is found 9 times the use of the personification language style; Hyperbolic language style ranks the second most widely used language style in student poetry, which is used 8 times; and repetition language style ranks last in the language style most widely used in student poetry, which is used 5 times. [9] The language style in the Najwa notebook and implementation at junior high school 2 in Balikpapan, the form of comparative language style found was 27 data, each consisting of 4 data of parable language style, 9 metaphorical language style, 9 personification language style data, Depersonification language style amounted to 4 data, and antithesis language style amounted to 1 data. From these results, it can be seen that najwa shihab is more dominant in using parable and personification with the same amount of 9 data. Second, the najwa notebook can be implemented as teaching material in Indonesian language learning in junior high schools.

[10 ] the language style of najwa eye speech title in Trans, with the results of the research that the dominant language style used is an eroretic or rhetorical question, while the dominant style of speech is cynicism. The use of speech style aims to help Najwa Shihab enter to express his ideas and emotions so that the use of language creates certain connotations and aesthetic values for both the speech partner and the audience of Mata Najwa's Talkshow and also by [11] This study aims to determine the types of satire language styles. which Najwa Shihab uses in the Najwa Notes book. This research uses a qualitative approach with descriptive methods.

Najwa sihap is a former news anchor on the Metro TV television station who often steals people's attention with his distinctive language style which has an extraordinary strategy to convey facts and opinions in an interesting and neat manner. [12] in his research entitled relationship marketing and najwa eyes as part of the marketing strategy of narasi.tv. This research wants to describe how the eye najwa program has contributed to popularizing narasi.tv. The positive image of the najwa's eyes, as well as the long-established relationship marketing with its viewers, has created a new audience segment, namely internet users who can access it online only on narasi.tv.

However, what distinguishes this research from previous research is that this research focuses on the figurative language style used by najwa sihab to insult the political elite on the issue of the release of corrupt prisoners for the sake of preventing corona in prison. Recently, the issue of releasing prisoners in order to prevent the spread of Covid 19 has been widely discussed and debated so that it has led to various debates and contradictions as well as in the narrative of corruptors being released because of corona? You will be on YouTube first. The following is a figurative language style in the narrative of corruptors being freed because of Corona, later:

"In principle, this reason is very acceptable. The conditions of our prisons are inhuman, people are piled up like pindang, even sleeping alternately."

The quote above is a simile style used by najwa sihab in his narrative, silime is a comparison that directly says something is the same as other people. [2] equation or simile is a comparative language style that is empirical. What is meant by an empirical comparison is that it immediately states one thing is the same as another, for that it requires efforts that explicitly show the similarity, namely words: like, equal, as, like, like and so on. The quote above explains in principle the reason for releasing prisoners in the midst of Covid 19 is acceptable because prison conditions are inhuman or abundant, people pile up like shelters and even sleep alternately because of the excess capacity of prisons in Indonesia.

The figurative language style is grouped into two, namely comparison and equation, the actual comparison contains two meanings, namely the comparison which is included in the plain or direct language style and the comparison which includes the figurative style. Therefore, this research is focused on the figurative language style contained in the narrative of the corruptors being released because of corona? You will be on Youtobe first. with the aim of seeing how the style of language used by najwa 
sihap to reveal the problem of corrupt discourse was freed because of the corona complete with the presentation of the data and facts.

\section{METHOD}

[13] Qualitative research is a study based on the collection, analysis, and interpretation of data in the form of narrative (not numbers) inobtaining an understanding of the observed phenomenon. The research method used in this research is descriptive method. Descriptive research is a method whose data sources are words, pictures and not numbers. In addition, all that is collected is likely to be the key to what has been studied [14]

The source of the data in this research is from Youtube with the narrative video of the corruptors being released because of the corona? Later, Najwa Sihab. This research technique is the technique of observing and takingnotes.

The observation and note-taking technique means that in this study the subject as a key instrument is listening carefully, directed, and carefully to the source of the data because in this listening activity the data is written data, namely speech / sentences in corruptors being freed because of the corona? You will be on YouTube first. which contains a figurative language style. Furthermore, the technique used in this research is the note taking technique. The note-taking technique in this research is to note the existence of a figurative language style in which corruptors are freed because of the corona? You will be on YouTube first.

[15] The data analysis technique was carried out by describing the respective data in a functional and relational manner. The data analysis activities of this study were carried out in the following steps. 1) The video that has been downloaded becomes data then the sentences are transcribed and the speech of the corruptors released because of the corona? Later, najwa will be at YouTube; 2) selecting data, analyzing all transcribed sentences and utterances of najwa sihab. Furthermore, choosing certain data relating to the problem, namely the figurative language style of corruptors being released because of corona? Later, najwa will be at YouTube; 3) data that has been classified in data collection techniques, then entered into the data tabulation table; 4) analyze according to figurative language style; 5) describe the results and analysis in accordance with the figurative language style of the corruptors being released because of corona? Later, najwa will be done on YouTube. Based on 6) data triangulation; and 7) formulate and draw a conclusion.

\section{RESULTS AND DISCUSSION}

[2] based on sentence structure, it is divided into climax, anti-climax, parallelism, antithesis, and repetition. Language style based on direct meaning is divided into rhetorical language styles which include alliteration, assonance, anastroph, apophasis or preterisio, apostrophe, acindetone, polysindetone, chiasmus, ellipsis, euphemismus, litotes, proteronic hysterone, pleonasm and tautology, perifrasis, prolepsis or anticipation, erothesis or rhetorical inquiry, silepsis and zeugma, correction or epanortosis, hyperbole, paradox, and oxynomorones. In addition, figurative language styles include similes or similes, metaphors, (allegories, parables, and fables), personification or prosopopoeia, allusions, eponyms, epithets, sinekdoke. Metonymy, antonomasia, hypalase, (irony, cynicism and sarcasm), satire, insuendo, antifrasis, pun or paronomasia. However, this research focuses on figurative language style only. The following is an example of the figurative language used by najwa sihab in the narrative of the corruptors being freed because of corona? Later, I'll be on YouTube first:

\section{a. Antonomasian Figurative Language}

the figurative language of Antomasia is also a special form of synekdoke which involves the use of an epitheta in place of one's own name, or an official title, or title in place of one's own name. Here is an example of the figurative language of Antomasia:

"So, the honorable Minister, so that we don't have any suspicion, try to open it to the public first, what corruption convicts and which ones occupy the cells jostling like a general prisoner who steals chickens who even sleeps in turns?"

The quotation finger above is an example of the figurative language style of Antomasia used by Najwa Sihab in his narrative to provide a figurative satire to the Minister, he used the words of the honorable minister, so that we are not suspicious of all kinds of things, try to open it to the public first, what corruption convicts and Where are those who occupy the cells jostling like a general prisoner who steals chickens who even sleeps in turns? "The quote above also emphasizes that we all publicly need an explanation from a minister that what corruption convicts and where do they occupy the jostling cell like general prisoners. chicken thieves who even have to take turns sleeping? " thus making the minister raise a discourse on the release of corrupt convicts as an effort to prevent the spread of Covid 19.

\section{b. Cynicism style}

cynicism is defined as the only satire in the form of doubt that contains ridicule and sincerity of heart. The following is an example of the figurative language of cynicism used by the najwa sihab in his narrative that the corruptors were released because of corona? Later, I'll be on YouTube first:

"Oh yes, if you really want to check corrupt prisons, please check again the cells of Papa Setya Novanto and his friends in Sukamiskin, still in the cell watching Netlifx, or are they having a meal at a Padang stall?"

The ditas quote is an example of the figurative language style of cynicism used by najwa to insinuate the political elite who used the covid 19 excuse to release corrupt convicts, he also insinuated about the difference in treatment between general inmates and corrupt convicts 
who were far different, so he used satire by saying all at once if indeed want to check corrupt prisons, leave another check on the cells of Papa Setya Novanto and his friends in Sukamiskin, still in their cell watching Netlifx, or are they enjoying themselves at a Padang stall? ", this sentence insinuates the political elite and opens our eyes all that it is. different needs between corrupt and general inmates while in prison. Another example of cynicism in the najwa narrative follows:

It is natural that a number of anti-corruption activists suspect that the policy of releasing corrupt convicts is just a trick. The Ministry of Law and Human Rights has tried several times to alleviate the punishment of corruptors through revision of laws and regulations. "

Kutian above explained how the najwa insinuated the political elite who made the public suspicious of his attitude. He said it was natural that a number of anticorruption activists suspected that the policy of releasing corrupt convicts was just a trick. The Ministry of Law and Human Rights has tried several times to alleviate the punishment of corruptors through the revision of laws and regulations. "This is complemented by data that several times the political elite plans to ease the punishment of corrupt convicts. This satire of course makes us realize that the discourse on the release of corrupt convicts is only a trick. trick.

\section{CONCLUSION}

Based on the results of the analysis and discussion previously described regarding the use of figurative language styles, it can be concluded that figurative language styles include similes, metaphors, (allegories, parables, and fables), personification or prosopopoeia, allusions, eponyms, epithets, synekdokes.

Metonymy, antonomasia, hypalase, (irony, cynicism and sarcasm), satire, insuendo, antifrasis, pun or paronomasia. However, this research focuses on figurative language style alone. It can be concluded that the language style is more dominant in the narrative because the corruptors were freed because of the corona? In the past, najwa sihab on YouTube is a figurative style of Antonomasia and cynicism.

\section{REFERENCES}

[1] Kridaklasana, H. (2011). Linguistic Dictionary Fourth Edition. Jakarta: Gramedia Pustaka Utama.

[2] Keraf, G. (2009). Dictionary and Language Style of Advanced Composition I Updated Edition. Jakarta: PT. Gramedia Pustaka Utama.

[3] Penthasa, D. (2019). "Ustadz Haikal Hasan's Lecture Style in Youtube Video". Thesis, Islamic Communication and Broadcasting Study Program, Faculty of Da'wah and Communication, Sunan Ampel State Islamic University, Surabaya.

http://digilib.uinsby.ac.id/35304/

[4] Anjani E. (2016). "KH Zainuddin MZ's Language Style in the Isra Mikraj Lecture at South
Tangerang". Journal of Research \& Development of Da'wah Management. Vol.09, No.1. Pages 161-185.

https://journal.uinsgd.ac.id/index.php/kelola/article/vie w/8088

[5] Rohmadi, A. (2016). "Ustad Maulana's Da'wah Language Style in Islamic Events is Beautiful and Its Implications in Learning Indonesian in High School". Thesis, Indonesian Language and Literature Study Program, Faculty of Teacher Training and Education, University of Lampung

http://www.inteleksia.stidalhadid.ac.id/index.php/int eleksia/article/view/17

[6] Alamsyah, F. (2017). "Diction and Language Style in the Tengku Hanan Attaki Religious Lecture". Journal of Bahasantodea. Vol. 5, No.2. Pages 14-23.

file: I/I C: /Users/Administrator/Downloads/1325941775-1-PB.pdf

[7] Shofwatul, B. (2019). Language Style in Imam Syafi'i's Diwan About the Commandment of Seeking Knowledge. National Seminar on Arabic for Students III in 2019 HMJ, Department of Arabic Literature, Faculty of Letters, State University of Malang. P-ISSN 2598-0637 2621-5632. https://books.google.co.id/books

[8] Risna, F. (2020). The Use of Language Styles in Poetry of Class VIII Students of SMP Negeri 1 Pasirkuda. Suryakancana University Cianjur. amics: Volume 3 (2) 2020 Journal of Language, Literature, Learning E-Issn 2715-8381

https://jurnal.unsur.ac.id/dinamika/article/download/100 $0 / 959$

[9] Nursahira, E. (2019). Analysis of language style in Najwa notebook and implementation at SMP 2 Balikpapan. Balikpapan University. Vol. 12, no. 1, June http://download.garuda.ristekdikti.go.id/article.php?arti cle $=1276646 \& v a l=16944 \&$ title $=$ ANALISIS $\% 20$ GAYA \%20BAHASA\%20DALAM\%20BUKU\%20CATATA N\%20NAJWA\%20DAN\%20IMPLEMENTASI\%20DI P\%20SMPN\%202\%20BALIKPAPAN

[10] Succi. (2019). rhetorical language style and allusion to najwa shihab in the najwa eye speech title in trans7 succy febriani 1, emidar2 Indonesian language education program fbs Padang State University Vol. 8 No. 3, September 2019; Series E 408-414

http://ejournal.unp.ac.id/index.php/pbs/article/download /108226/103259

[11] Siti, N. (2019). najwa shihab satire language style in the najwa siti notebook Nurul halimah1, hilda hilaliyah2 language education study program Indonesia, faculty of language and arts, private university pgri. Vol. 11 no. 02, May-August 2019 https://www.researchgate.net/publication/337676683_G aya_Bahasa_Sindiran_Najwa_Shihab_dalam_Buku_Ca tatan_Najwa

[12] Ravinoldy, B (2019). Relationship Marketing and Najwa's Eyes as Part of a Marketing Strategy Narasi.tv. London School of Public 
Relations. Ultimacomm Journal Vol. 11, No. 2, Dec http://ejournals.umn.ac.id/index.php/FIKOM/article/do wnload/1178/821

[13] Leo, S. (2013). Tips for Writing Thesis, Thesis, and Dissertation. Jakarta: Erlangga Publisher.
[14] Moleong, L. (2013). Qualitative Research Methodology. Bandung: Youth Rosdakarya. [15] Siswantoro. (2010). Literary Research Methods. Yogyakarta: Learning Library. 